\title{
Factors Influencing Breast Milk Feeding in Singleton Late Preterm Infants
}

\author{
Su Jin Kim', Gun Ja Jang² \\ ${ }^{1}$ Doctoral Student, Department of Nursing, Eulji University, Daejeon; ${ }^{2}$ Professor, Department of Nursing, Daegu University, Daegu, Korea
}

\begin{abstract}
Objectives: The purpose of this study was to identify predictors of breast milk feeding at one month after hospital discharge in singleton late preterm infants (LPIs). Methods: This was a secondary analysis of data obtained from two published studies related to breastfeeding for late preterm infants. Data were a total of 244 LPIs' feeding type at one month after discharge and analyzed using the chi-square test and t-test to compare demographic and feeding-related characteristics between breast milk feeding and formula feeding group. Predictors associated with breast milk feeding were identified by logistic regression analysis. Results: Feeding type of LPIs' hospitalization was a predictor of breast milk feeding at one month. LPIs fed breast milk exclusively or partially in the hospital were more likely to maintain breast milk feeding at home. Conclusions: This result showed that breastfeeding support and encouragement in clinical settings was a decisive factor in improving breast milk feeding in singleton LPIs.
\end{abstract}

Key words: Breast milk, Formula, Preterm, Singleton

\section{INTRODUCTION}

In Korea, the number of babies has gradually decreased from 465,900 in 2008 to 326,000 in 2018. However, the preterm birth rate has increased from 5.5\% in 2008 to $7.8 \%$ in 2018 [1]. Late preterm infants (LPIs) born at $340 / 7$ to 36 6/7 weeks gestation account for two-thirds of premature babies [2]. The physical and neuromuscular immaturities of LPIs cause various health issues such as respiratory distress, jaundice, hypoglycemia, and feeding difficulties [3-5]. In particular, LPIs' feeding difficulties just after birth fail to initiate breastfeeding and poor breastfeeding establishment [3]. Therefore, LPIs have more significant risks for lower breastfeeding rates at discharge and postpartum than that of term infants or even more premature neonates born less than 34 weeks of gestation [6-8].

While breast milk is the most optimized nutrition for all infants, it is especially important to infants born early and have an insufficient immune response and immature organs, including the brain [9]. Besides, the World Health Organization (WHO) recommends that mothers should exclusively breastfeed infants for the first six months without any supple-

Corresponding author: Gun Ja Jang

33 Seongdang-ro 50-gil, Nam-gu, Daegu 42400, Korea

E-mail: kjjang14@daegu.ac.kr

Received: November 2, 2020 Revised: November 22, 2020 Accepted: November 24, 2020

No potential conflict of interest relevant to this article was reported. mented food [10]. That's the reason why health care providers have efforts to improve breastfeeding for LPIs. Despite these recommendations, the breastfeeding rate of Korean LPIs is very low because few hospitals in Korea have standard guidelines for successful breastfeeding establishment for LPIs and their mothers. However, there are clinical protocols developed by The Academy of Breastfeeding Medicine for the care of breastfeeding mothers and LPIs in the US [11].

Most research related to LPIs' breastfeeding has focuses on breastfeeding rates and interventions for breastfeeding in clinical settings during hospital admission [5,12]. A comparative study on the breastfeeding rate of LPIs with early term infants and term infants reported that breastfeeding one month postpartum was significantly associated with the gestational age [7]. An intervention study on the effects of the infant care education program in Korean LPIs reported that breastfeeding rates in the intervention group were improved than those of the control group [12]. An integrative review of thirteen intervention studies to enhance breastfeeding in the LPIs asserted that interventions positively affected exclusivity and duration of breastfeeding [5].

How to cite this article:

Kim SJ, Jang GJ. Factors influencing breast milk feeding in singleton late preterm infants. J Health Info Stat 2020;45(4):311-316. Doi: https://doi.org/10.21032/jhis.2020.45.4.311

(c) It is identical to the Creative Commons Attribution Non-Commercial License (https://creativecommons.org/licenses/by-nc/4.0) which permit sunrestricted non-commercial use, distribution and reproduction in any medium, provided the original work is properly cited.

(c) 2020 Journal of Health Informatics and Statistics 
The study for breastfeeding for a certain period of postpartum beyond clinical settings should be needed. Therefore, this study was to identify predictors for singleton LPIs' breastmilk feeding one month after discharge. A study population was limited to singletons because twin LPIs were less likely to be breastfed than singleton LPIs $[13,14]$.

\section{METHODS}

\section{Study design and participants}

This was a secondary analysis study using data subtracted from two published studies. The one was a study [15] of comparison of feeding method by gestational age in LPIs, and the other was a study [16] of the prevalence of exclusive breastfeeding from the first week through 12 weeks after discharge in LPIs. From two studies, data of demographic and clinical characteristics of singleton LPIs and their mothers and feeding type at one month were used, but twins' data were excluded.

From a study [15], 233 LPIs delivered in four university hospitals in Daegu were gathered, and 208 LPIs' feeding type one month after discharge were additionally identified by researchers' phone calls and text messages. From the other study [16], 106 LPIs admitted in one university hospital in Daegu were gathered, and LPIs' feeding methods were investigated from the first week to the twelve-week after discharge.

Participants in this study were 244 LPIs, 172 in a study [15] and 72 in the other study [16]. Of 233 LPIs in a study [15], 36 twin LPIs were excluded, and then 25 LPIs whose mothers did not respond to a survey about feeding type at one month after discharge by phone calls or text messages. Of 106 LPIs in the other study [16], 34 twin LPIs were excluded.

\section{Feeding type}

Feeding type at one month was classified into the following three types: exclusive breast milk feeding, mixed feeding, and formula feeding. Exclusive breast milk feeding was defined as direct feeding at the breast or bottle-feeding with expressed breast milk. Mixed feeding referred to a combination of breast milk feeding and formula feeding. Formula feeding was defined as being exclusively formula-fed.

Breast milk feeding in this study included exclusive breast milk feeding and mixed feeding. The reason why mixed feeding was included in breast milk feeding was that there were few exclusive breastfeeding LPIs at one month. Besides, LPIs' mothers tended to supplement formula with breast milk feeding to improve LPIs' weight gain.

\section{Statistical analysis}

Data were analyzed using SPSS 25.0 software (IBM Co., Armonk, NY, USA). Feeding type of singleton LPIs at one month was analyzed number and percentage. To explore different participants' demographic characteristics and feeding-related characteristics between breast milk feeding and formula group. Independent t-test or ANOVA test were used. Predictors for breast milk feeding were identified using logistic regression analysis.

\section{Ethical considerations}

This study obtained Institutional Review Board approval from Daegu University (IRB No. 1040621-201905-HR-023-02).

\section{RESULTS}

\section{Feeding type of the singleton late preterm infants}

The feeding type of singleton LPIs at one month after discharge, formula, mixed, and breast milk feeding were $61.5 \%, 28.7 \%$, and $9.8 \%$, respectively (Table 1).

\section{Comparison of participants' demographic characteristics according to feeding type}

There were no significant differences in demographic characteristics between breast milk feeding and formula feeding groups. In gestational age, the number of 36 weeks of LPIs was high in the formula group while 35 weeks of LPIs in the breast milk feeding group. The total hospital stay of the formula feeding group (12.83 days) was shorter than that of breast milk feeding (14.24 days) (Table 2). Two-thirds of LPIs in both groups were delivered by Cesarean section.

\section{Comparison of participants' feeding-related characteristics according to feeding types}

There were no significant differences of feeding-related characteristics between breast milk feeding and formula feeding groups except feeding

Table 1. Feeding type at one month after discharge in singleton late preterm infants $(n=244)$

\begin{tabular}{lc}
\hline Category & $\mathrm{n}(\%)$ \\
\hline Formula feeding & $150(61.5)$ \\
Breast milk feeding & $24(9.8)$ \\
Mixed feeding & $70(28.7)$ \\
\hline
\end{tabular}


Table 2. Comparison of general characteristics between formula and breast mild feeding group ( $n=244)$

\begin{tabular}{|c|c|c|c|c|c|c|}
\hline \multirow{2}{*}{ Subject } & \multirow{2}{*}{ Characteristics } & \multirow{2}{*}{ Category } & FF group $(n=150)$ & BMF group $(n=94)$ & \multirow{2}{*}{$\chi^{2} / t$} & \multirow{2}{*}{$p$} \\
\hline & & & \multicolumn{2}{|c|}{$\mathrm{n}(\%)$ or $\mathrm{M} \pm \mathrm{SD}$} & & \\
\hline \multirow[t]{14}{*}{ Infant } & Birth weight (g) & & $2,532.27 \pm 436.64$ & $2,464.47 \pm 369.67$ & 1.25 & 0.212 \\
\hline & Gender & Male & $86(57.3)$ & $50(53.2)$ & -0.63 & 0.528 \\
\hline & & Female & $64(42.7)$ & $44(46.8)$ & & \\
\hline & Birth order & First-born & $81(54.0)$ & $60(63.8)$ & 1.63 & 0.198 \\
\hline & & Second-born & $46(30.7)$ & $26(27.7)$ & & \\
\hline & & $\geq$ Third-born & $23(15.3)$ & $8(8.5)$ & & \\
\hline & Gestational age (wk) & 34 & $31(20.7)$ & $28(29.8)$ & 1.66 & 0.192 \\
\hline & & 35 & $59(39.3)$ & $37(39.4)$ & & \\
\hline & & 36 & $60(40.0)$ & $29(30.9)$ & & \\
\hline & Disease of newborn & Yes & $44(29.3)$ & $18(19.1)$ & -1.85 & 0.067 \\
\hline & & No & $106(70.7)$ & $76(80.9)$ & & \\
\hline & Apgar score (1-min) & & $7.03 \pm 1.04$ & $6.77 \pm 1.28$ & 1.79 & 0.075 \\
\hline & Apgar score (5-min) & & $8.42 \pm 0.90$ & $8.17 \pm 1.04$ & 1.98 & 0.058 \\
\hline & Total hospital stay (day) & & $12.83 \pm 7.05$ & $14.24 \pm 7.81$ & -1.47 & 0.144 \\
\hline \multirow[t]{7}{*}{ Mother } & Age (y) & & $32.98 \pm 4.40$ & $32.32 \pm 4.51$ & 1.02 & 0.038 \\
\hline & Employment & No & $128(85.3)$ & $73(77.7)$ & -1.49 & 0.143 \\
\hline & & Yes & $22(14.7)$ & $21(22.3)$ & & \\
\hline & Maternal disease & No & $105(70.0)$ & 73 (77.7) & 1.34 & 0.183 \\
\hline & & Yes & $45(30.0)$ & $21(22.3)$ & & \\
\hline & Type of delivery & Vaginal & $41(27.3)$ & $34(36.2)$ & 1.43 & 0.154 \\
\hline & & Cesarean section & $109(72.7)$ & $60(63.8)$ & & \\
\hline
\end{tabular}

$\mathrm{M} \pm \mathrm{SD}$, mean \pm standard deviation; FF, formula feeding; BMF, breast milk feeding.

Table 3. Comparison of feeding-related characteristics between formula and breastfeeding group $(n=244)$

\begin{tabular}{|c|c|c|c|c|c|}
\hline \multirow{2}{*}{ Characteristics } & \multirow{2}{*}{ Category } & FF group $(n=150)$ & BMF group $(n=94)$ & \multirow{2}{*}{$\chi^{2 / t}$} & \multirow{2}{*}{$p$} \\
\hline & & \multicolumn{2}{|c|}{$\mathrm{n}(\%)$ or Mean $\pm \mathrm{SD}$} & & \\
\hline Hospital days at first feeding & & $2.57 \pm 2.05$ & $2.94 \pm 2.68$ & -1.19 & 0.234 \\
\hline Infant's body weight at first feeding (g) & & $2,454.90 \pm 444.69$ & $2,381.81 \pm 359.09$ & 1.34 & 0.181 \\
\hline Feeding days during hospitalization & & $10.95 \pm 6.29$ & $12.16 \pm 6.84$ & -1.41 & 0.160 \\
\hline \multirow[t]{2}{*}{ Feeding intolerance } & No & $82(54.7)$ & $59(62.8)$ & 1.25 & 0.211 \\
\hline & Yes & $68(45.3)$ & $35(37.2)$ & & \\
\hline \multirow[t]{3}{*}{ Feeding method during hospitalization } & Formula & $72(48.0)$ & $11(11.7)$ & 24.04 & $<0.001$ \\
\hline & Breast-milk & $1(0.7)$ & $9(9.6)$ & & \\
\hline & Mixed & $77(51.3)$ & $74(78.7)$ & & \\
\hline
\end{tabular}

SD, standard deviation; FF, formula feeding; BMF, breast milk feeding.

type during hospitalization. The number of mixed feeding or exclusive breast milk feeding in the BMF group was more than that of the FF group, while the number of formula feeding in the BMF group was lower than that of the FF group (Table 3).

\section{Predictors related to breast milk feeding in singleton late preterm infants}

Given that predictor for breast milk feeding of singleton LPIs at one month after discharge was feeding type during hospitalization, LPIs fed
Table 4. Predictor related to breast milk feeding one month in singleton late preterm infants $(n=244)$

\begin{tabular}{|c|c|c|c|c|c|}
\hline Variables & Categories & $\mathrm{B}(\mathrm{SE})$ & OR & $95 \% \mathrm{Cl}$ & $p$ \\
\hline (Constant) & & $-0.04(0.16)$ & & & \\
\hline \multirow{3}{*}{$\begin{array}{l}\text { Feeding } \\
\text { method during } \\
\text { hospitalization }\end{array}$} & Formula & & & & \\
\hline & Breast-milk & $-1.84(0.36)$ & 0.16 & $0.08-0.32$ & $<0.001$ \\
\hline & Mixed & $2.24(1.07)$ & 9.37 & $1.16-75.75$ & 0.036 \\
\hline \multicolumn{6}{|c|}{-2 Log Likelihood $=280.71, \chi^{2}(2)=44.58, p<0.001$, Nagelkerke $R^{2}=0.23$} \\
\hline
\end{tabular}

$\mathrm{SE}$, standard error; $\mathrm{OR}$, odds ratio; $\mathrm{Cl}$, confidence interval. 
mixed feeding in hospitals were 0.16 times more likely to continue breastfeeding at one month, and those of breast milk feeding was 9.37 times more likely to last during the same period (Table 4).

\section{DISCUSSION}

Because breastfeeding and human milk are the most suitable way to nourish infants, it is essential to promote breast milk consumption during the first six months of life [5,17]. Given that breast milk contains immunological and anti-infective components that prevent various infectious diseases, LPIs who have not been transferred immunological factors from mothers at the late stage of pregnancy need to be breastfed [18]. Postpartum of 4 to 8 weeks is considered a crucial period to establish exclusive breastfeeding infants and allow mothers to nurture their babies [16]. This study was performed to identify predictors of breast milk feeding of singleton LPIs at one month after discharge.

In terms of feeding type of singleton LPIs, formula feeding (61.5\%) was higher than mixed feeding (28.7\%) and breast milk feeding (9.8\%) at one month after discharge. About $38.5 \%$ of any breast milk feeding in this study was lower findings of previous studies reporting $63.8 \%$ of breastfeeding at one month postpartum in LPIs [7] and 75.4\% of breastfeeding at six weeks in UK LPIs [19]. This finding was also lowered $40.7 \%$ of breastfeeding at one month after discharge in LPIs who did not receive a breastfeeding education [12]. Above all, less than $10 \%$ of exclusive breastfeeding in this study was far lower than the international recommendation for breastfeeding by the World Health Organization [10]. This poor breastfeeding practice in LPIs can be explained by the physiological and physical immaturities of LPIs, which is regarded as the most crucial influencing factor for the failure of breastfeeding [3-5]. The statement that LPIs requires a unique set of interventions for successful breastfeeding establishment because they often have greater challenges with breastfeeding [20] supports the results of this study.

Feeding type during hospitalization was a factor that influences breast milk feeding in singleton LPIs. In other words, LPIs who were provided with breast milk are likely to continue breast milk feeding at home, comparing LPIs who were only formula-fed. This finding was consistent with another study [21], reporting feeding method during hospitalization was one of the factors influencing breastfeeding for LPIs. However, studies $[13,22]$ reporting mothers' sociodemographic variables, including age, education, and smoking status, were associated with breastfeeding were different from this study. In addition, the finding that late preterm birth itself is predictive of breastfeeding failure was different from this result [23]. Although LPIs are greater risks at breastfeeding initiation and continuation, just 16.4\% of LPIs experienced hospital support, compared with 30.7\% of term infants [23]. This finding supports that breastfeeding education and support in hospitals improves the possibility of any breastfeeding at home.

This study's limitation is that it did not include mothers' psychological factors like breastfeeding efficacy, confidence, and empowerment. Therefore, it suggests that further studies, including mothers' multidimensional variables, are needed to determine breast milk feeding predictors in singleton LPIs.

\section{CONCLUSIONS}

This study showed that feeding type during hospitalization was a crucial influencing factor at one month after discharge singleton late preterm infants. Mothers of LPIs who are well educated about breastfeeding LPIs from just after delivery are likely to continue breastfeeding at home. This highlights the nurses' role in breastfeeding education and support in clinical settings.

\section{ORCID}

Su Jin Kim ～https://orcid.org/0000-0001-9266-1575

Gun Ja Jang https://orcid.org/0000-0002-1028-8066

\section{REFERENCES}

1. Korean Statistical Information Service. 2018 Live births by period of pregnancy. Available at http://kostat.go.kr/portal/korea/kor_nw/1/1/ index.board?bmode=read\&aSeq=377055 [accessed on January 6, 2020].

2. Engle WA. A recommendation for the definition of "late preterm" (near-term) and the birth weight-gestational age classification system. Semin Perinatol 2006;30(1):2-7. DOI: 10.1053/j.semperi.2006.01.007

3. Cooper BM, Holditch-Davis D, Verklan MT, Fraser-Askin D, Lamp J, Santa-Donato A, et al. Newborn clinical outcomes of the AWHONN late preterm infant research-based practice project. J Obstet Gynecol Neonatal Nurs 2012;41(6):774-785. DOI: 10.1111/j.1552-6909.2012. 01401.x 
4. Na JY, Park N, Kim ES, Lee HJ, Shim GH, Lee JA, et al. Short-term clinical outcomes of late preterm infants. Korean J Pediatr 2009;52(3): 303-309 (Korean). DOI: 10.3345/kjp.2009.52.3.303

5. Cartwright J, Atz T, Newman S, Mueller M, Demirci JR. Integrative review of interventions to promote breastfeeding in the late preterm infant. J Obstet Gynecol Neonatal Nurs 2017;46(3):347-356. DOI: 10.1016/j.jogn.2017.01.006

6. Jang GJ, Lee SL, Kim HM. Breast feeding rates and factors influencing breast feeding practice in late preterm infants: comparison with preterm born at less than 34 weeks of gestation age. J Korean Acad Nurs 2012;42(2):181-189 (Korean). DOI: 10.4040/jkan.2012.42.2.181

7. Hackman NM, Alligood-Percoco N, Martin A, Zhu J, Kjerulff KH. Reduced breastfeeding rates in firstborn late preterm and early term infants. Breastfeed Med 2016;11(3):119-125. DOI: 10.1089/bfm.2015. 0122

8. Hwang SS, Lu E, Cui X, Diop H, Barfield WD. Home care practices for preterm and term infants after hospital discharge in Massachusetts, 2007 to 2010. J Peinatol 2015;35(10):880-884. DOI: 10.1038/jp.2015.90

9. Lapillonne A, O'Connor DL, Wang D, Rigo J. Nutritional recommendations for the late-preterm infant and the preterm infant after hospital discharge. J Pediatr 2013;162(3 Supple):S90-100. DOI: 10.1016/j. jpeds.2012.11.058

10. World Health Organization. Indicators for assessing infant and young child feeding practices. Part 1: definitions. Available at http://www.who. int/maternal_child_adolescent/documents/9789241596664/en/ [accessed on May 10, 2020].

11. Academy of Breastfeeding Medicine. ABM clinical protocol \#10: Breastfeeding the late preterm infant (34(0/7) to 36(6/7) weeks gestation) (first revision June 2011). Breastfeed Med 2011;6(3):151-156. DOI: 10.1089/ bfm.2011.9990

12. Jang EH, Ju HO. Effects of an infant care education program for mothers of late-preterm-infants on parenting confidence, breastfeeding rates, and infants' growth and readmission rates. Child Health Nurs Res 2020; 26(1):11-22 (Korean). DOI: 10.4094/chnr.2020.26.1.11

13. McDonald SD, Pullenayegum E, Chapman B, Vera C, Giglia L, Fusch C, et al. Prevalence and predictors of exlusive breastfeeding at hospital discharge. Obstet Gynecol 2012;119(6):1171-1179. DOI: 10.1097/AOG. 0b013e31825619b

14. Kim BY. Factors that influence early breastfeeding of singletons and twins in Korea: a retrospective study. Int Breastfeed J 2017;12(4):1-10. DOI: 10.1186/s13006-016-0094-5

15. Jang GJ. Comparing factors associated with breastfeeding in late preterm infants of different gestational ages. Child Health Nurs Res 2015; 21(4):302-310 (Korean). DOI: 10.4094/chnr.2015.21.4.302

16. Lee SY, Jang GJ. Prevalence and predictors of exclusive breastfeeding in late preterm infants at 12 weeks. Child Health Nurs Res 2016;22(2):7996 (Korean). DOI: 10.4094/chnr.2016.22.2.79

17. Section on Breastfeeding. Breastfeeding and the use of human milk. Pediatrics 2012;129(3):e827-e841. DOI: 10.1542/peds.2011-3552

18. Beattie LM, Weaver LT. Mothers, babies and friendly bacteria. Arch Dis Child Fetal Neonatal Ed 2011;96(3):F160-F163. DOI: 10.1136/adc. 2010.189639

19. Rayfield S, Oakley L, Quigley MA. Association between breastfeeding support and breastfeeding rates in the UK: a comparison of late preterm and term infants. BMJ Open 2015;5(11):e009144. DOI: 10.1136/bmjopen-2015-009144

20. Briere C, Lucas R, McGrath JM, Lussier M, Brownell E. Establishing breastfeeding with the late preterm infants in the NICU. J Obstet Gynecol Neonatal Nurs 2015;44(1):102-113. DOI: 10.1111/1552-6909. 12536

21. Jang GJ, Lee SL, Kim HM. Breast feeding rates and factors influencing breast feeding practice in late preterm infants: Comparison with preterm born at less than 34 weeks of gestational age. J Korean Acad Nurs 2012;42(2):181-189 (Korean). DOI: 10.4040/jkan.2012.42.2.181

22. Demirci JR, Sereika SM, Bogen D. Prevalence and predictors of early breastfeeding among late preterm mother-infant dyads. Breastfeed Med 2013;8(3):277-285. DOI: 10.1089/bfm.2012.0075

23. Goyal NK, Attanasio LB, Kozhimannil KB. Hospital care and early breastfeeding outcomes among late preterm, early-term, and term infants. Birth 2014;41(4):330-338. DOI: 10.1111/birt.12135 


\section{국문초록}

\section{단태 후기 미숙아의 모유수유 영향 요인}

\section{김수진'장군자 ${ }^{2}$}

'을지대학교 간호대학 박사졸업, ${ }^{2}$ 대구대학교 간호학과 교수

목적: 본 연구는 단태 후기 미숙아의 병원 퇴원 후 1개월 시점에서 모유수유 영향요인을 규명하기 위함이다.

방법: 후기 미숙아의 모유수유 실천율과 관련된 2개 선행 연구에서 쌍태아를 제외하고 단태아 데이터를 활용한 이차분석연구이다. 후 기 미숙아 244 명의 퇴원 1 개월 시점 수유형태의 데이터를 활용하였고, 모유수유군과 조제유군 간 일반적 특성 및 수유관련 특성은 chisquare test와 t-test, 모유수유 영향 요인은 로지스틱 회귀 분석으로 분석하였다.

결과: 후기 미숙아의 퇴원 1 개월 모유수유에 영향을 미치는 요인은 병원 입원 기간 동안의 수유형태였다. 즉, 병원에서 완전 모유수유 를 하거나 혼합유를 통해 모유를 제공받은 경우 퇴원 후에도 모유수유를 지속하는 것으로 나타났다.

결론: 후기 미숙아의 입원 동안 임상에서 모유수유를 적극적으로 지지하고 권장하는 것이 단태 미숙아의 모유수유를 증진하는 중요 한 요인임을 밝히는 바이다.

주제어: 모유수유, 분유, 미숙아, 단태 